\title{
Paleolake records as sedimentary proxies of climate changes of Northern Eurasia in the past
}

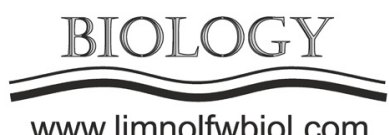

www.limnolfwbiol.com

\author{
Subetto D.A . ${ }^{1}$, Fedotov A.P. ${ }^{2}$ \\ ${ }^{1}$ Herzen State Pedagogical University of Russia, Nab. Moyki 48, St. Petersburg, 191186, Russia \\ ${ }^{2}$ Limnological Institute Siberian Branch of the Russian Academy of Sciences, Ulan-Batorskaya Str., 3, Irkutsk 664033, Russia
}

For the development and testing of plausible scenarios of possible climate changes in the near future, it is important to understand whether modern climate changes are unique or there were palaeoanalogues. Of equal importance is to infer the response of biotic and abiotic systems to past global and regional climate changes to understand processes and response thresholds to changes as well as to provide reliable analogues, where it is possible, for likely future ecosystem states.

In Northern Eurasia, there is a great number of various lakes, whose bottom sediments archived detailed records of changes in climate, landscapes, the evolution of lakes, and their ecosystems in the Pleistocene and Holocene. For a long time, the lakes of the northern latitudes have been poorly studied due to their inaccessible geographical position. However, in recent decades, research work has been actively carried out to study bottom sediments of lakes in the north of Eurasia as well as to make paleogeographic and paleoclimatic reconstructions. New original data have been obtained within the framework of international projects aimed to study the history of the lakes of Yakutia, such as lakes Bilyakh, Satagay, Bolshoye Toko and others, whose history covers a time interval of up to 30-40 ka. The Russian-German paleolimnological project, RLOT (Paleogeographic transect), was carried out along the submeridional transect on lakes Ladoga, Shchuchye (Polar Urals), Taimyr, and Emanda (Yakutia), which correlated the paleogeographic history from these lakes with the previously obtained data on the meteorite Lake Elgygytgyn. Paleolimnological studies of the level dynamics of large water basins along the periphery of the Baltic crystalline shield (the Baltic Sea, lakes Ladoga and Onega, and the White Sea) as well as identification of the causes and mechanisms of sharp climatic changes in the LGM-Holocene transition are being actively carried out.

Paleolimnological conferences in the USSR were regularly held every three years from the 1960s to the 1980s. The conference "Paleolimnology of Northern Eurasia" continues this tradition. The first three conferences have been organized by Northern Water
Problems Institute of the Karelian Research Centre RAS (Petrozavodsk, Russia), North-Eastern Federal University (Yakutsk, Russia), Kazan Federal University (Kazan, Russia) in 2014, 2016 and 2018, respectively. This 4th International Conference "Palaeolimnology of Northern Eurasia" is to be held in Limnological Institute of the Siberian Branch of RAS. Notably, the year of 2019 was the 60th anniversary of the first paleolimnological laboratory in the USSR established at the Limnological Institute Siberian Branch of the USSR Academy of Sciences. Martinson G.G (1911-1977) first headed the paleolimnological studies in the USSR.

This special issue presents 73 studies in: i) Paleogeographic reconstructions and GIS modelling; ii) Sedimentation and geochemistry of bottom sediments; iii) Bio-indicators of changes in the aquatic environment and climate. Studied paleo-objects from shallow waters (less than $1 \mathrm{~km}^{2}$ ) of the largest lakes Baikal, Onega and Ladoga are located from $19^{\circ} 40^{\prime} \mathrm{E}$ to $145^{\circ} 45^{\prime} \mathrm{E}-175^{\circ} \mathrm{W}$ and from 72 ' $\mathrm{N}$ to $38^{\circ} 36^{\prime} \mathrm{N}$. The main discussion concerning climate changes is related to the LGM and Holocene.

All these studies demonstrate the range of techniques available to decipher and interpret very different records of environmental change. Furthermore, they illustrate the ability to the past to understand the present and update our knowledge, as we negotiate the measures to deal with an uncertain future under increasing anthropogenic pressure of a rapidly changing environment.

\section{Acknowledgements}

We are grateful to all of the authors who contributed to this special issue, reviewers of all the papers. This special issue stems from presentations made at 4th International Conference on Paleolimnology of Northern Eurasia, from 02 to 04 September 2020, Irkutsk, Russia. This conference was organised under financial support of the Russian Foundation for Basic Research, project No.20-05-22013, Helicon Company and SibLabService Company. 